\title{
Groundwater Recharge, Evapotranspiration and Surface Runoff Estimation Using WetSpass Modeling Method in Illala Catchment, Northern Ethiopia
}

\author{
Teklebirhan Arefaine ${ }^{1 *}$, Dessie Nedaw ${ }^{2}$, Tesfamichael Gebreyohannes ${ }^{2}$ \\ $1_{*}$ Department of Water resource and irrigation management, College of Agriculture, P.O. Box \\ 314, Aksum University, Aksum, Ethiopia \\ 2 Department of Earth Science, CNCS, P.O. Box 231, Mekelle University, Mekelle, Ethiopia
}

Hydrometeorological information is important in planning and management of natural resources. The northern Ethiopia in general and Illala sub-basin in particular is lacking reliable information with regard to groundwater recharge, evapotranspiration and surface runoff. The main objective of the study is to estimate the distributed groundwater recharge, surface runoff and evapotranspiration amount of Illala sub basin using WetSpass modeling method. Long term mean hydrometeorological data and physical characteristics of the catchment such as land use/land cover, soil type, topography, groundwater level and slope are used as an input to the model. The mean annual groundwater recharge, evapotranspiration and runoff were found to be 66, 440 and 40mm respectively. Accordingly, recharge accounts for $12 \%$ of the precipitation while the rest $81 \%$ and $7 \%$ becomes evapotranspiration and surface runoff respectively. The study area is characterized by low groundwater recharge due to the presence of high evapotranspiration rate associated with high temperature, dry wind, low rainfall and relative humidity though it is a little bit large compared to some parts of the northern Ethiopia.

Key words: Groundwater, WetSpass, Recharge, Illala, Catchment, Tigray, Ethiopia.

\section{INTRODUCTION}

Groundwater recharge is the process by which water percolates down the soil and reaches the water table either by natural or artificial methods to replenish the aquifer with water from the land surface. In arid and semi-arid areas, its assessment is a key challenge in determining sustainable yield of aquifers (Yongxin and Beekman, 2003; Crosbie et al., 2010). The same is true in many parts of Ethiopia like Tigray region where being semiarid it remains dry for major part of the year.

Recharge is estimated by chloride ion mass balance method, empirical method, water-balance method, water budget model method or by multiplying the magnitude of water-level fluctuations in wells with the specific yield of the aquifer material. But commonly groundwater recharge is determined to a large extent as an imbalance at the land surface between precipitation and evaporative demand (Gebreryfael, 2008). Now, with the advent of Geographic Information Systems (GIS), physical-based hydrologic modeling has become important in contemporary hydrology for assessing these parameters as well as the impact of human intervention and/or 
possible climatic change on basin hydrology and water resources (Alemaw and Chaoka, 2003). Hence, WetSpass was built as a physically based methodology for estimation of the long-term average, spatially varying, water balance components: surface runoff, actual evapotranspiration and groundwater recharge (Batelaan and De Smedt, 2001, 2007).It is an acronym for water and energy transfer between soil, plants and atmosphere under quasi-steady state that was built upon the foundations of the time dependent spatially distributed water balance model (Batelaan and De Smedt, 2001, 2007).

From a volume perspective, most water use in Illala catchment is appropriated from groundwater. Since the rainfall of the catchment is seasonal, most of the time, the tributaries and the main river are ephemeral. Hence, this forces the local communities to use subsurface water not only for drinking but also for domestic and in some cases for irrigation purpose. Though this groundwater is recharged from precipitation, utilization of this resource is going on without a basic understanding of the recharge amount and its areal distribution as well as the temporal and spatial variation of the other water balance components which creates a critical problem for its management in the catchment. Hence, estimation of rates of groundwater recharge in the area is crucial for sustainable utilization of the resource as well as its protection against pollution and depletion. In this paper groundwater recharge, surface runoff and evapotranspiration is estimated for the Illala catchment using WetSpass modeling method.

\section{AREA OF STUDY}

\subsection{Location, topography and soil type}

The study area is located in the northern part of Ethiopia between N13 $27^{\prime}-13^{0} 35^{\prime}$ and E $39^{0} 22^{\prime}$ -

$39^{\circ} 43^{\prime}$ (Fig 1). The Illala catchment covers an area of about $340 \mathrm{~km}^{2}$ with an elevation ranging from $1739 \mathrm{~m}$ at the outlet to $2671 \mathrm{~m}$ at its source (Fig 1). The river flows following the weak zone which is affected by faults and dolerite intrusions. Almost all its discharge occurs during the rainy season with a flood that lasts for a short period. Field observation indicated that the catchment to be characterized by a graben-like structure bounded by NNW-SSE aligned ridges. The western part is associated with pronounced flat lands than the eastern part (Fig 2). Soils of the study area are classified into five classes based on their grain size using the United States Department of Agriculture (USDA) textural classification methods, sandy loam, clay loam, loam, sandy clay loam and clay. 


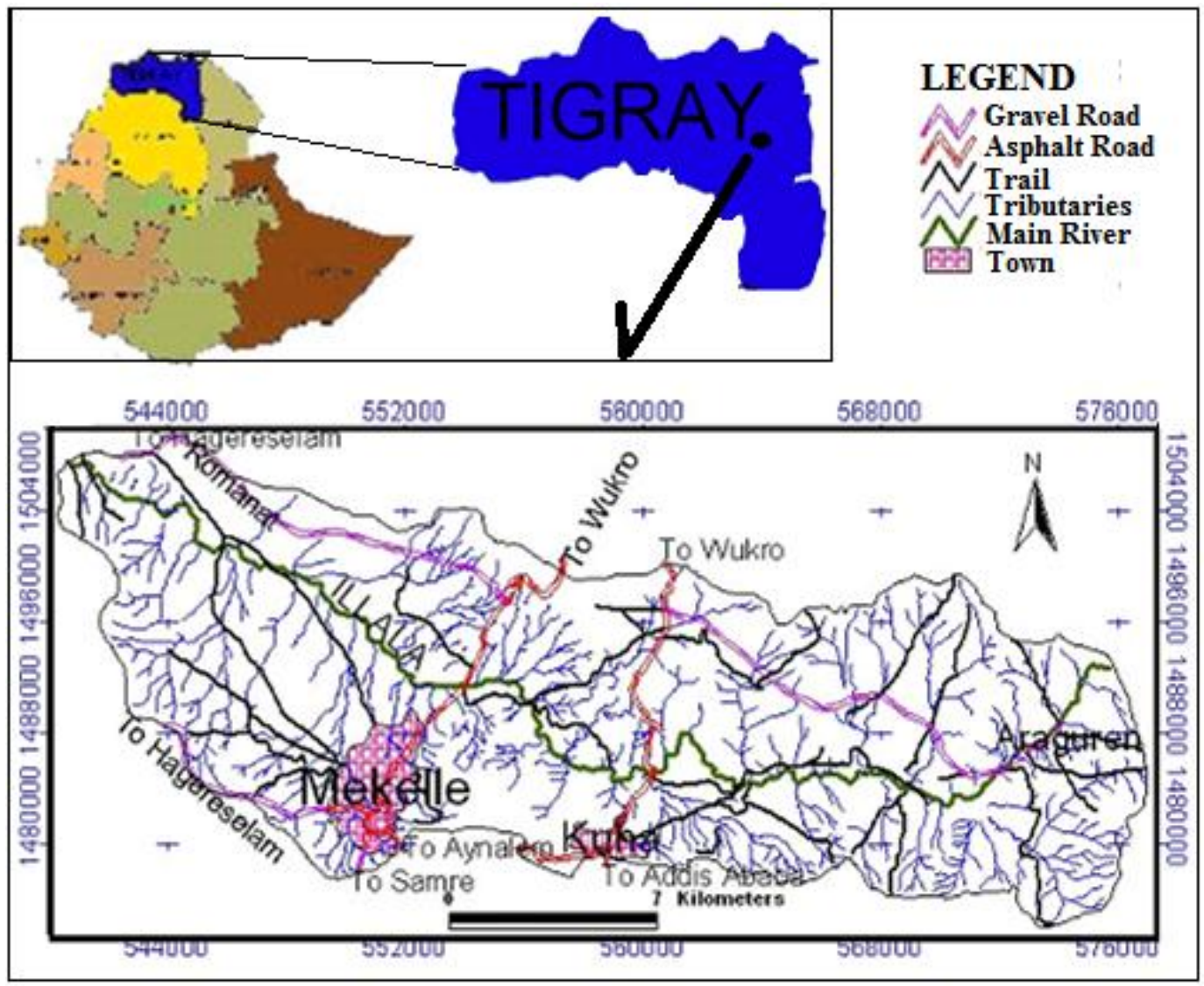

Figure 1. Location map of Illala catchment.

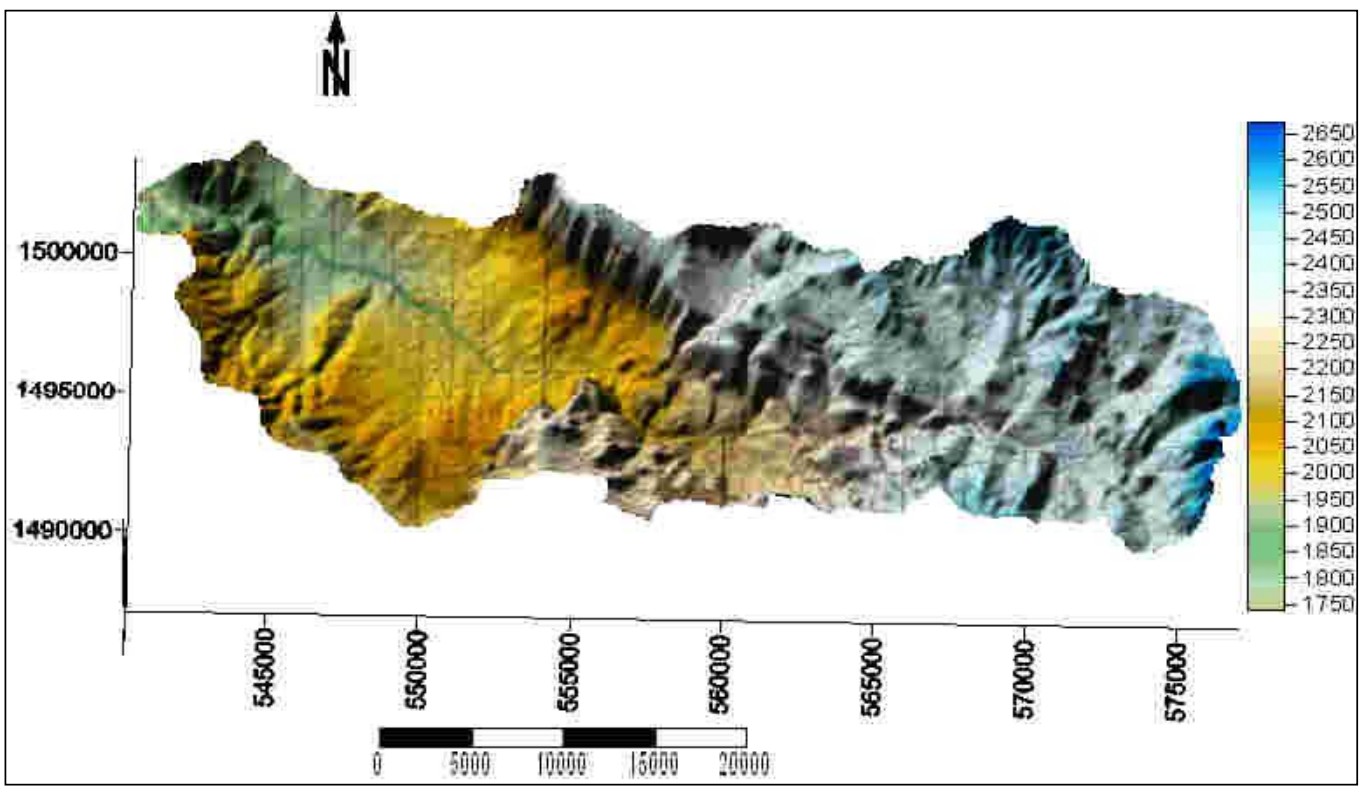

Figure 2. Digital elevation model of Illala catchment, Tigray. 


\subsection{Land use/ land cover, climate and vegetation}

Land-use/land-cover is a major controlling factor of watershed hydrology (Fetter, 2001).Landuse/land-cover of the area is dominated by cultivated land, bush land, forest, rural and urban settlement (Fig 3). The cultivated land which consists $64 \%$ of the land cover is distributed throughout the study area. Besides, it is the principal land-use of the catchment.

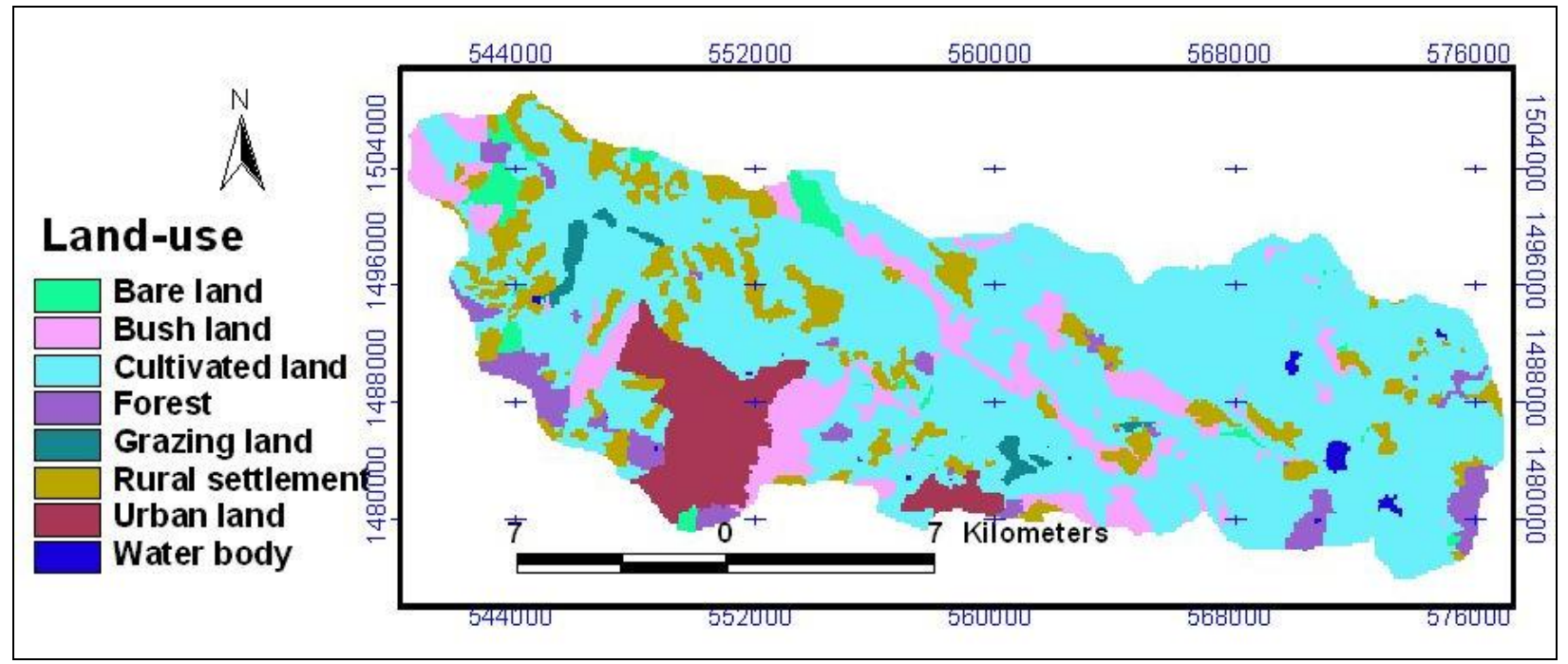

Figure 3. Land-use map of Illala catchment, Tigray.

Forest land accounts $4.1 \%$ which includes areas covered by eucalyptus trees, olea and acacia species. Bush land covers about $10.4 \%$ of the catchment which is dominated by acacia species. Rural and urban settlement consists of $10.8 \%$ and $7.1 \%$, respectively while the remaining $0.5 \%$, $1 \%$ and $2.1 \%$ of the area are covered by water body, grazing and bare land respectively (Fig 3).

\subsection{Geological and hydrogeological set up of the study area}

The geology of Illala catchment is highly disturbed due to volcanic eruptions and dolor tic sills/dykes. Geology of the catchment is mainly dominated by limestone-shale-marl intercalation, limestone, dolerite and Quaternary sediments (Fig 4). Locally, the intensity of fracturing and faulting as well as the degree of weathering determines the aquifer potential and direct infiltration of the rock (Tesfaye and Gebretsadik, 1982). Hydrogeological conditions of Illala catchment is mainly controlled by the lithologies, geological structures and geomorphology. Geological structures like faults and fractures play a principal role in groundwater movement and permeability of the catchment. 


\subsubsection{Limestone}

In this unit, there are caves in the central part of the catchment along the riverbank. But towards both directions caves are reduced due to presence of shale and intrusion of dolerite as a result of low solution formation. Solution cavities, karstification, joints and travertine are also found in this unit at different parts of the catchment. Hence, in the catchment, the limestone formation has appreciable secondary porosity and permeability as result of fracturing and opening along and across the bedding planes. Wells drilled in this area yields up to 5 liters per second. In general, the limestone of the catchment can be taken as a moderately permeable aquifer (Fig 4).

\subsubsection{Limestone -shale-marl intercalation}

Mostly, this unit is dominated by limestone with intercalation of thin beddings of shale and marl. There are various low discharges springs which are emerging at contact of the limestone and shale-marl beds with discharges not more than $0.5 \mathrm{l} / \mathrm{sec}$. The permeability of this rock in northwestern and other parts of the catchment (Fig 4) shows a moderate value due to the presence of secondary porosity that developed as a result of fracturing and weathering.

\subsubsection{Dolerite}

This unit occurs as sills/dykes mainly in the limestone-shale-marl intercalation. Joints are common with 2- $8 \mathrm{~cm}$ openings. Moreover, it shows fracturing and weathering. Hence, in some areas it facilitates infiltration until it reaches the massive part. This is evidenced by existence of high discharge springs in some parts of the study area, which reach about 1 1/s, emerging at the depressed areas of the dolerite unit. So, with increasing depth, the dolerite becomes massive. Generally as figure 4 indicates, the dolerite unit of the study area is characterized with a very low to low permeability in the catchment though the fractured zone moderate degree of permeability.

\subsubsection{Quaternary sediments}

These sediments are formed due to erosion and depositional processes. However, erosion decrease currently due to different soil and water conservation practices conducted especially in some areas of the upper catchment. Since these sediments consist, proportions of different grain sizes that are transported from various parent materials; they become very important for infiltration and storage of groundwater. Their transmitting capacity and productivity vary from place to place depending on their grain size, sorting and thickness. Accordingly, these sediments range from low to high permeability (Fig 4). 


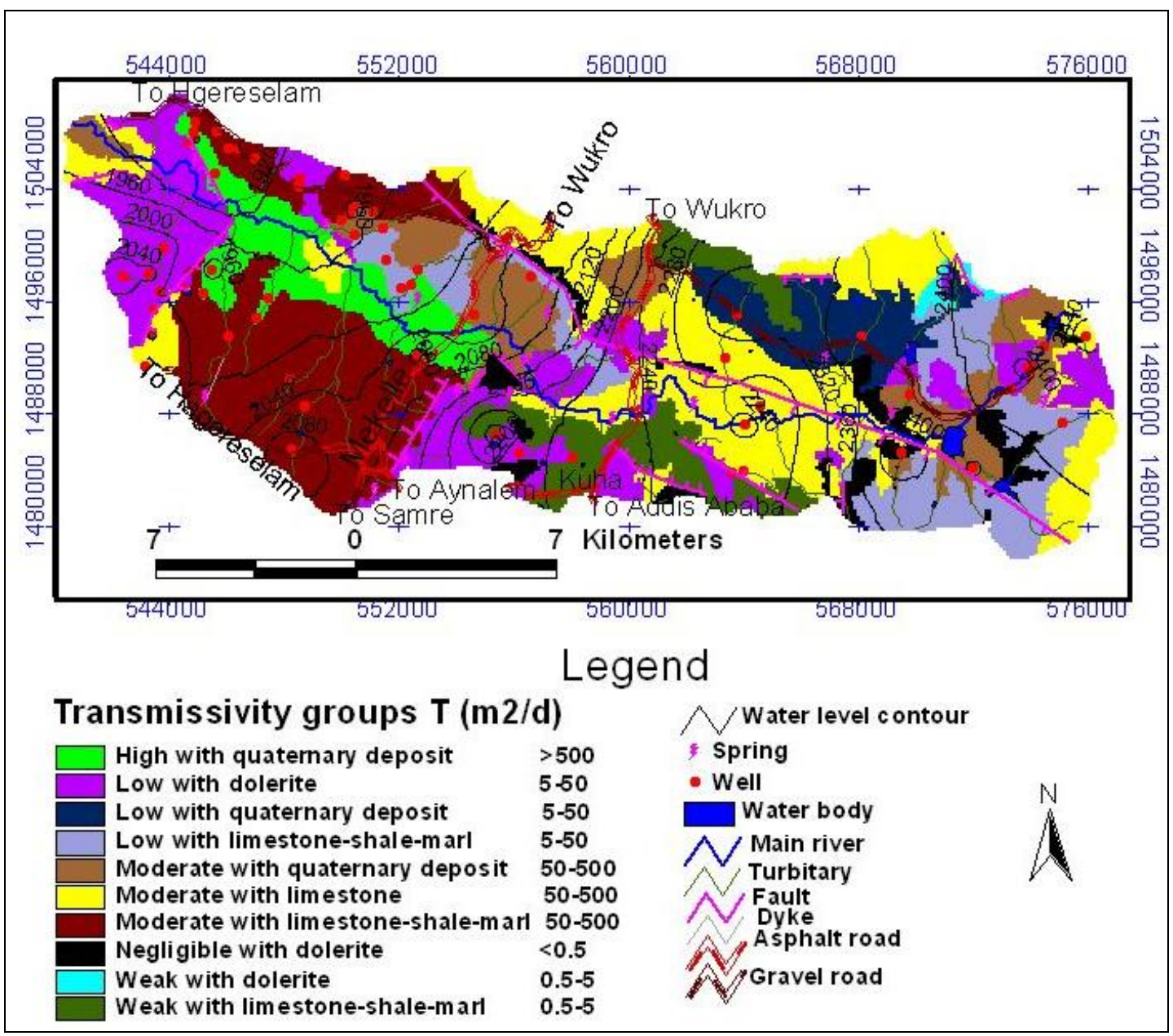

Figure 4. Hydrogeological map of Illala catchment (compiled and modified from Tesfaye and Gebretsadik, 1978; Tesfamichael, 2009; WWDSE, 2007; Girmay, 2011).

\section{METHODOLOGY}

Seventeen soil samples were collected based on soil color, landuse, landform, geology and field methods of soil testing using stratified sampling techniques. The sampling sites are distributed all over the catchment. They were collected by digging pits (subsurface profiles). The collected samples were analyzed in Tigray Agricultural Research Center laboratory. The land use and land cover map is produced using Landsat TM7satellite image taken in 2002 and field delineation by using GPS.

WetSpass modeling method was used to estimate groundwater recharge of the study area. As WetSpass modeling was developed for temperate regions by Batelaan and DeSmedt (2001, 2007), which has different climatic and land conditions compared to the tropics, some input parameters modification is used to apply it in tropical region. In temperate region, summer and 
winter have six month each while in Ethiopia summer contains four months and winter covers eight months. In addition to this, the seasons of rainfall period and land-use/land-cover are not the same. So, to apply the WetSpass for Illala catchment, input of the meteorological grid map was done using eight months of winter and four months of summer. Also, modified summer and winter land-use parameter tables were used.

Two types of inputs are required so as to run the WetSpass model: Parameter tables (dbf data) and grid map. ArcView (version 3.2) together with its spatial analyst extensions were used in order to prepare these input parameters. Inputs of landuse, soil and runoff characteristics parameter tables were required. Then, these tables were added to the maps as attribute. The runoff characteristics parameter tables contain runoff coefficient, slope and soil type for each corresponding landuse. In addition, since values in these tables are considered to be universal, no modifications are required for parameters of these tables. Topography, slope, landuse, soil, reference evapotranspiration and groundwater level maps were prepared. Hence, the topographic grid map, which is used to characterize the horizontal hydrological characteristics of the land surface and the slope data layer, describes the maximum change in elevations were derived from SRTM using global mapper software. Due to the lack of monthly data for groundwater depth, same map input were used for both seasons. Temperature, precipitation and wind speed parameters were prepared using the available meteorological data collected from national meteorological agency.

\section{RESULTS AND DISCUSSION}

\subsection{Hydro-meteorological data analysis}

To estimate hydrologic balance for a given basin, each of the hydro-meteorological elements has to be quantified. Accordingly, rainfall, actual evapotranspiration, runoff and groundwater recharge have been estimated.

\subsubsection{Rainfall}

The rainfall pattern of the catchment is mono-modal type (Fig5) with $83 \%$ of the rainfall occurring in wet season (i.e. June-September). The rest $17 \%$ occurs in the dry season from October to May. The spatial distribution of rainfall is shown in figure 6. 


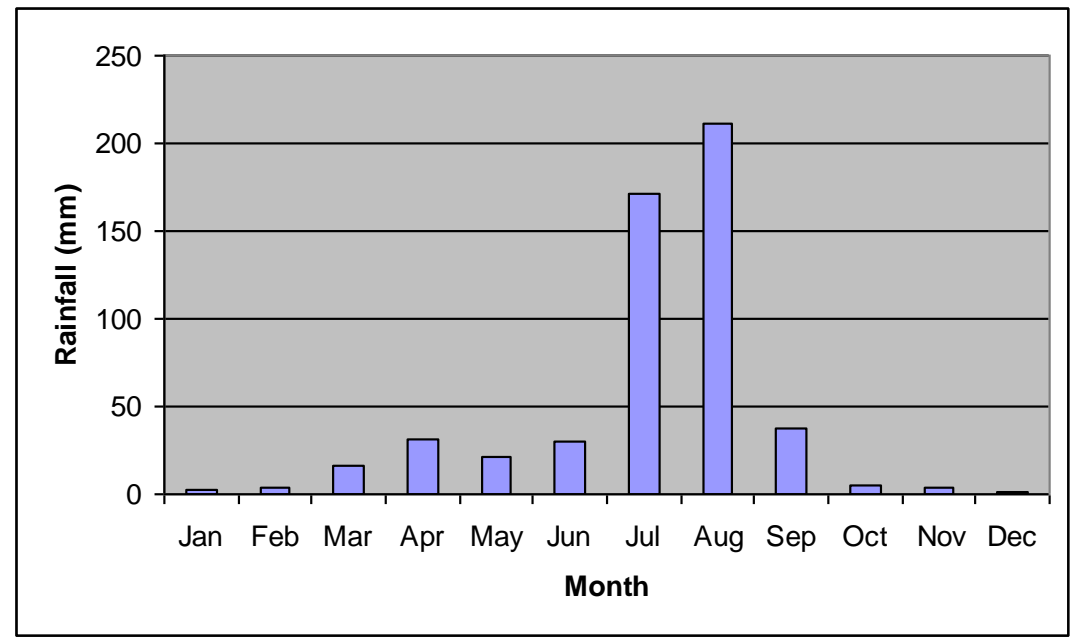

Figure 5. Mean monthly rainfall of Illala catchment, Tigray.

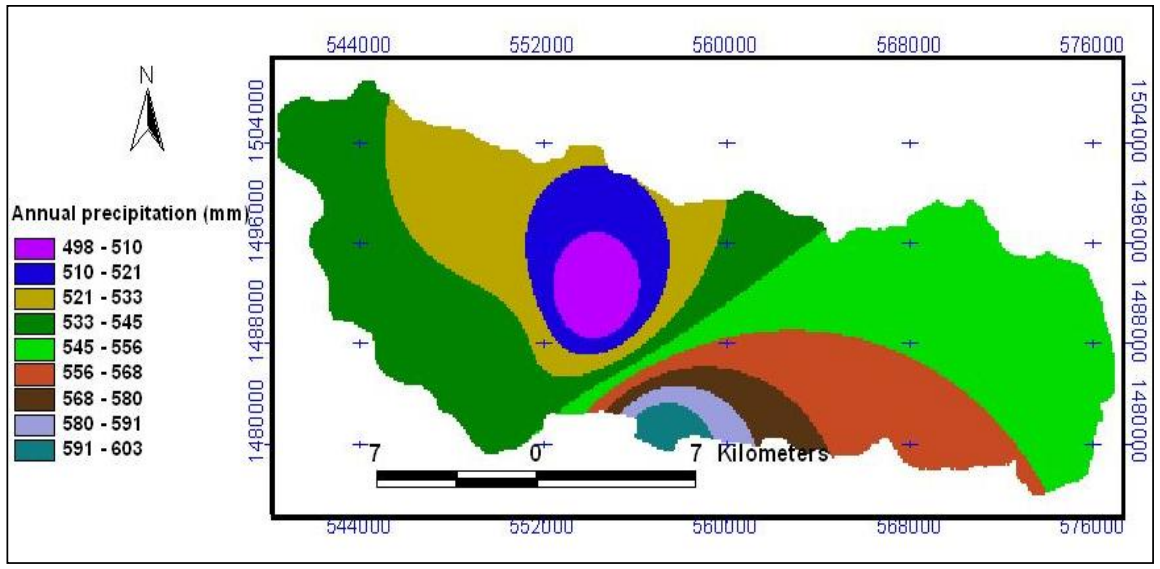

Figure 6. Rainfall distribution map of Illala catchment, Tigray.

\subsubsection{Potential evapotranspiration}

Potential evapotranspiration can be determined in different methods. But so as to assure a well distributed contour grid map of potential evapotranspiration of the catchment, an equation developed by Seleshi (2002) that relates potential evapotranspiration and altitude with regression equation for Tekeze and Mereb basin was used (Table 1). Moreover, to check the reliability of this method to the area, PET is also calculated using the FAO Penman-Monteith method. Potential evapotranspiration calculated using the two methods is given in figure 7. Therefore, as it is clearly seen in the figure 7 , the reference potential evapotranspiration determined from the two methods are more or less similar. 


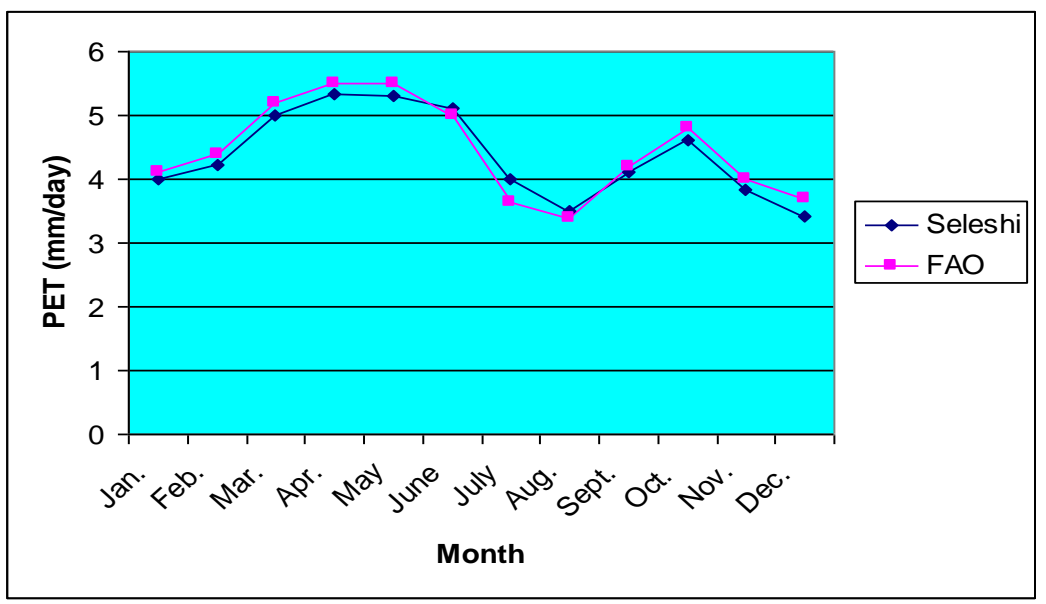

Figure 7. Daily mean potential evapotranspiration (PET) calculated using the FAO PenmanMonteith and Seleshi (2002) methods.

Table 1.Tekeze and Mereb basin monthly reference evapotranspiration (PET) and altitude relationships: $\mathrm{Y}=$ PET (mm/day), $\mathrm{X}=$ Altitude $(\mathrm{m})$ (Seleshi, 2002).

\begin{tabular}{|llll|}
\hline Month & Regression equation & Month & Regression equation \\
\hline January & $\mathrm{Y}=-0.0007 \mathrm{X}+5.3209$ & July & $\mathrm{Y}=-0.8656 \ln (\mathrm{X})+10.681$ \\
\hline February & $\mathrm{Y}=-0.0009 \mathrm{X}+6.2027$ & August & $\mathrm{Y}=-0.5021 \ln (\mathrm{X})+7.3998$ \\
\hline March & $\mathrm{Y}=-0.0009 \mathrm{X}+6.8341$ & September & $\mathrm{Y}=-0.0005 \mathrm{X}+5.1666$ \\
\hline April & $\mathrm{Y}=-0.0009 \mathrm{X}+7.3190$ & October & $\mathrm{Y}=-0.0007 \mathrm{X}+6.1164$ \\
\hline May & $\mathrm{Y}=-0.0007 \mathrm{X}+6.8455$ & November & $\mathrm{Y}=-0.0008 \mathrm{X}+5.6112$ \\
\hline June & $\mathrm{Y}=-0.0007 \mathrm{X}+6.6180$ & December & $\mathrm{Y}=-0.0008 \mathrm{X}+5.2040$ \\
\hline
\end{tabular}

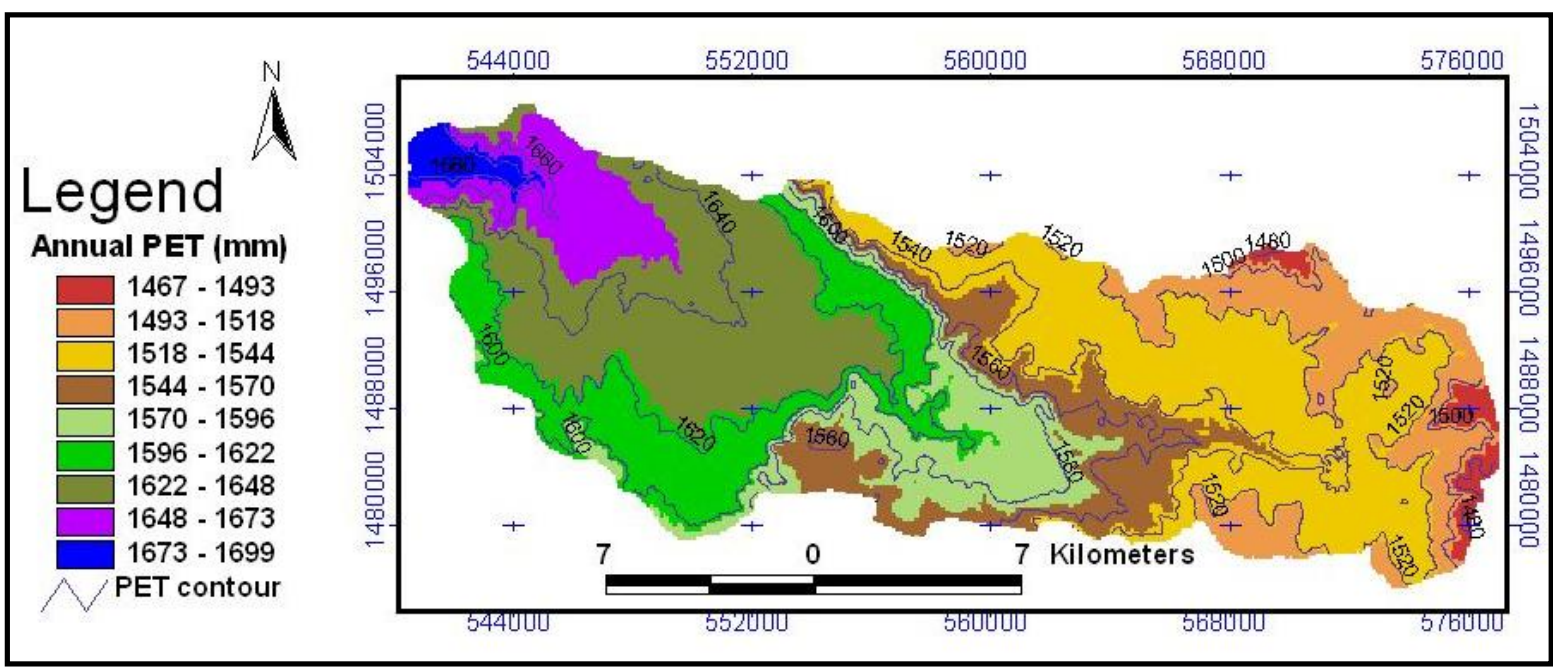

Figure 8. Annual reference potential evapotranspiration map of Illala catchment.

According to the annual reference potential evapotranspiration map (Fig 8), the reference potential evapotranspiration value is highest in western part of Illala around the outlet while it has lowest value in the eastern part around Araguren. 


\subsection{Out puts of the WetSpass model}

Annual groundwater recharge, annual actual evapotranspiration and annual surface runoff are the main outputs of the WetSpass model. A brief description of these outputs is given below:

\subsubsection{Evapotranspiration}

The annual evapotranspiration is calculated by WetSpass as a sum of evaporation from bare soil, transpiration of the vegetated cover, interception loss by vegetation and evaporations of open water body. Actual evapotranspiration is one components of water balance to determine groundwater recharge of Illala catchment using the WetSpass model. About $440 \mathrm{~mm}$ of water is lost through evapotranspiration from the catchment. This accounts for $81 \%$ of the catchment's annual precipitation. This shows that evapotranspiration is the main process by which water is lost in the catchment. This is attributed due to the high rate of radiation and the dry wind. About $79 \%$ of the total annual evapotranspiration is lost during summer season while the rest $21 \%$ is released in the winter season. This variation occurs due to difference in precipitation within the two seasons.

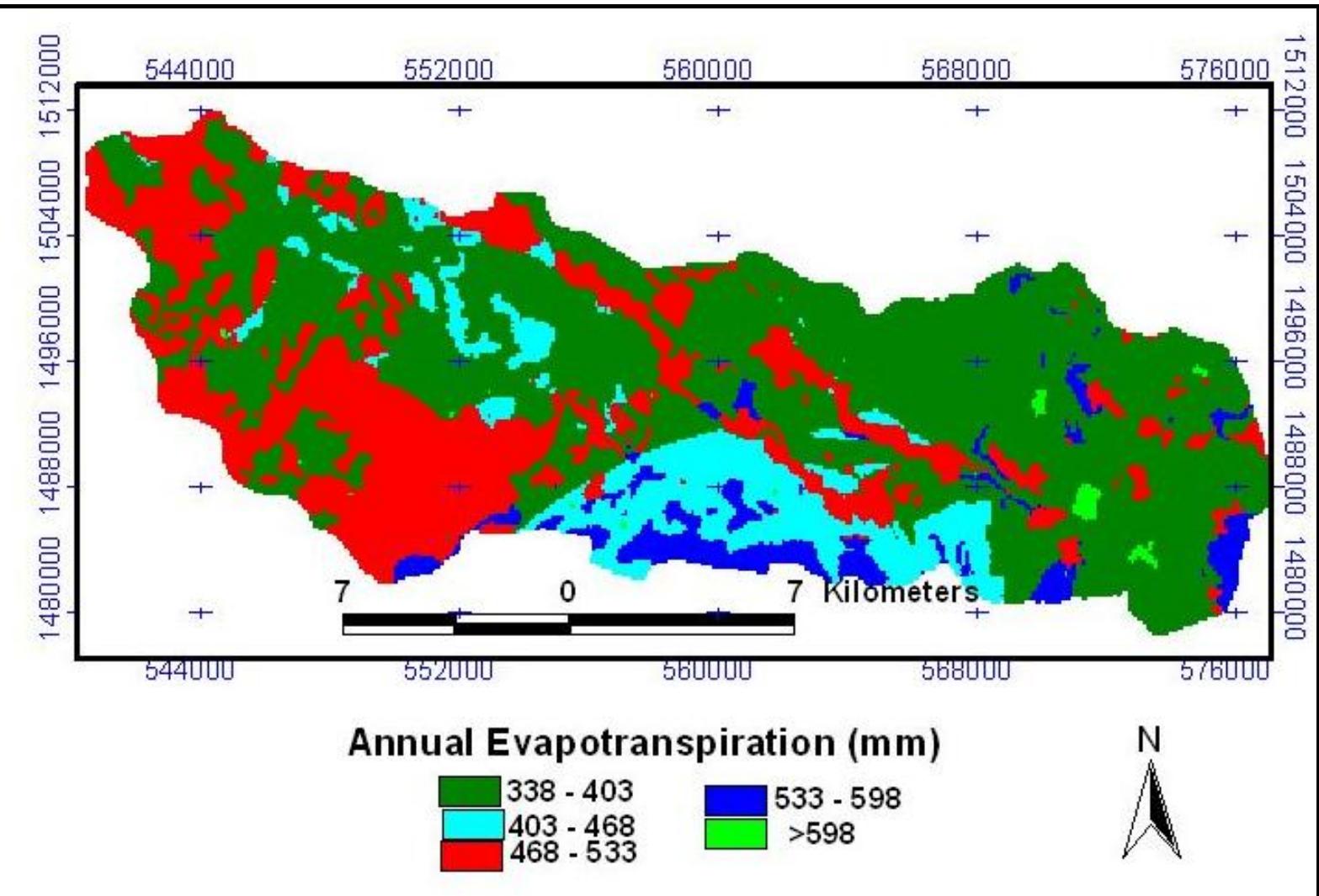

Figure 9. Annual actual evapotranspiration maps of Illala catchment. 
According to the WetSpass simulated results of annual evapotranspiration, its value ranges from 338 to $1638 \mathrm{~mm}$ in the catchment. The annual evapotranspiration map (Fig 9) shows that low annual evapotranspiration is observed in north-western part of the catchment which receives lower annual rainfall. This is clearly distinguished in the rural settlement of the specified area. Moreover, when considering the whole catchment; the lower part of the catchment has low evapotranspiration value which is due to low rainfall while the upper part has high evapotranspiration due to high precipitation, though the land-use and soil types are similar. Open water bodies have an annual evapotranspiration values the same with potential evapotranspiration which indicates there is enough supplies of water to keep this values of evaporation (Fig 9). Precipitation and land-use/land-cover are found to be the main controlling factors of evapotranspiration in the catchment.

\subsubsection{Surface runoff}

To estimate the surface runoff of Illala catchment WetSpass uses runoff coefficient which varies its value with vegetation type, soil type and slope. The surface runoff of Illala catchment shows variation with land-use, soil type, slope, topography, precipitation and the other meteorological parameters (Fig 10).

The amount of surface runoff also shows variation in summer and winter season. Surface runoff in the Illala basin ranges from 0 to $191 \mathrm{~mm}$ with 40 and $39 \mathrm{~mm}$ of mean and standard deviation value respectively. The mean value represents $7 \%$ of the total annual precipitations of Illala. From this, about $93 \%$ of the surface runoff occurs during the wet months (June to September) while the remaining 7\% occurs during the dry months (October to May). This variation comes from rainfall difference in the two seasons. The rainfall exceeds the infiltration capacity of the soil during the wet season. This leads to high surface runoff.

According to the annually simulated surface runoff of the catchment (Fig 10), the north-eastern part of the catchment has highest surface runoff due to the presence of clay soil which has a low permeability that enhance for surface runoff. On the other hand, the western part of the catchment near Illala outlet, south western part, southern part around Kuha, south eastern part, northern part and some areas near Araguren has less surface runoff. This is caused due to sandy loam and loam soil types associated with forest and shrubs coverage of the area which hinder surface runoff. This shows these soil types have great impact on annual surface runoff of Illala catchment. 
All land-use with sandy loam and loam soil yield the lowest surface runoff while rural settlement and agricultural land use types with clay soil yield the highest amounts of surface runoff in the catchment. Therefore, surface runoff is more governed by soil type when compared to landuse/land-cover type and slope in the study area.

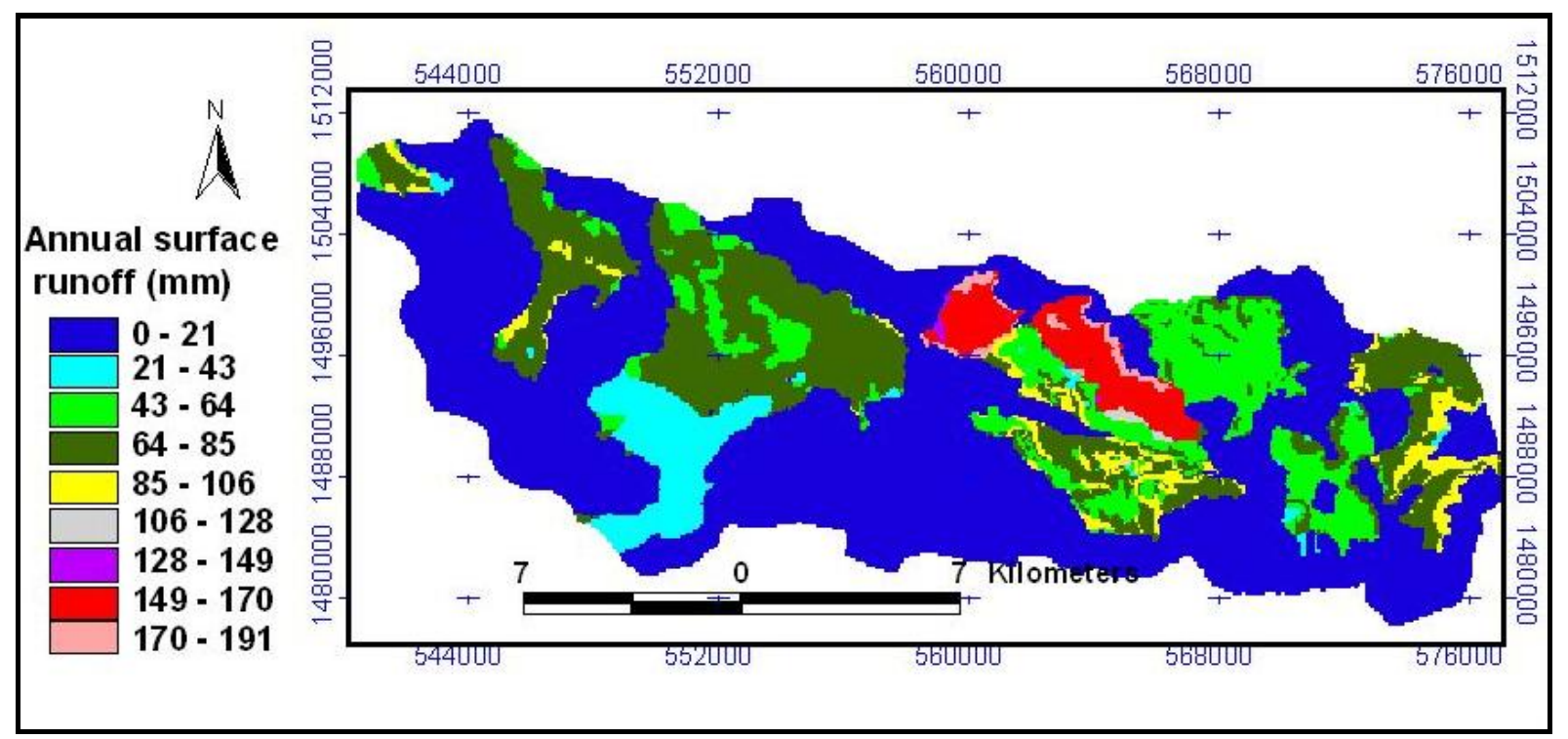

Figure 10.Annual surface runoff map of Illala catchment.

\subsubsection{Groundwater recharge}

The WetSpass model estimates seasonal and annual long term spatial distribution amounts of groundwater recharge of Illala catchment by subtracting the seasonal and annual surface runoff and evapotranspiration from the seasonal and annual precipitation respectively. The annual groundwater recharge of Illala catchment varies from 0 to $163 \mathrm{~mm}$ with $66 \mathrm{~mm}$ mean value (12\% of the annual precipitation). The result obtained has a similarity with the groundwater recharge estimated by Zeru for Aynalem which accounts $11 \%$ of the total rainfall (Zeru, 2008) that has similar climate with Illala as well as Samuel's result of Aynalem and lower parts of Illala (near Messobo) which accounts $53 \mathrm{~mm} /$ year or $9.2 \%$ of the mean annual precipitation (Samuel, 2003). About 95\%annual groundwater recharge of the catchment is occurred during the wet season (summer) while the rest $5 \%$ is occurred in dry season (winter).The southern part of the catchment around Kuha, south eastern part, north-eastern part and some south western parts of the area have generally high annual groundwater recharge due to the presence of permeable soils, high precipitation and less vegetations cover. On the contrary, the south western parts around Mekelle town, western part near Illala outlet, north western part near Mesobo as well as north eastern 
parts of the catchment have less amounts of recharge due to low precipitation, impermeable soils and overcrowded settlements (Fig 11).

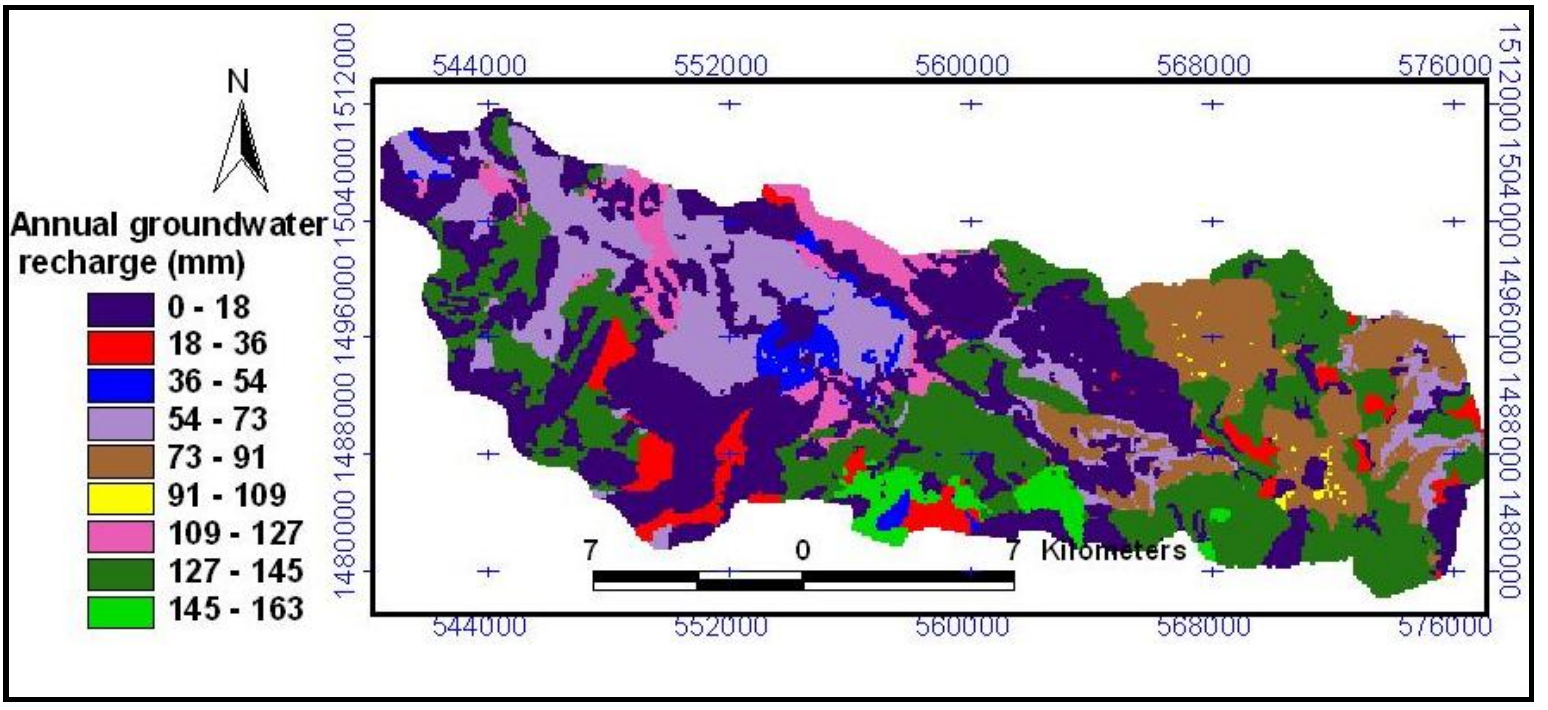

Figure 11.Annual groundwater recharge maps of Illala catchment.

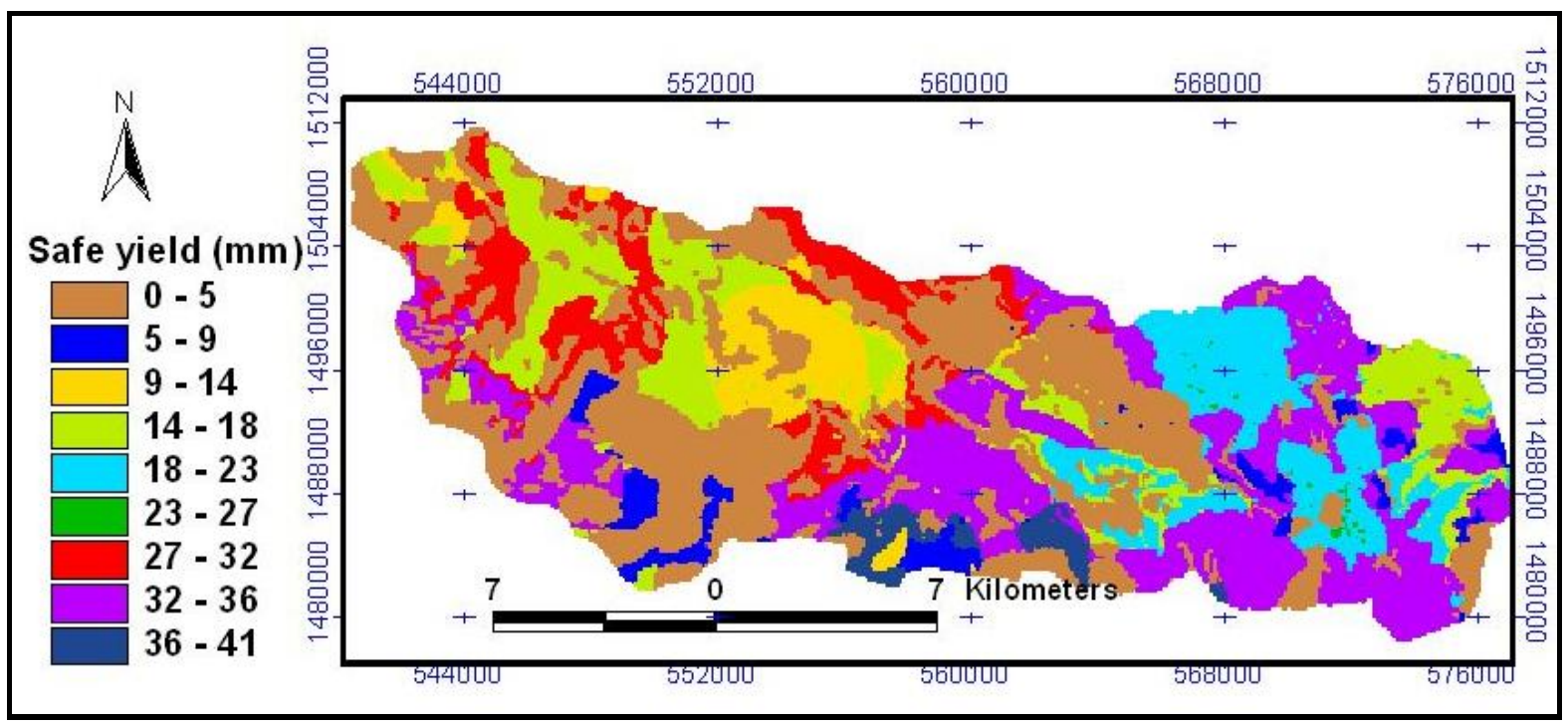

Figure 12. Groundwater safe yield map of Illala catchment.

In general high values of groundwater recharge are observed in the bare-and cultivated land with sandy loam and loam soils. This is due to good permeability of these soils and gentle topography. But all types of soils with forest, shrub and grazing land-use areas have resulted low amounts of groundwater recharge. This is caused due to the release of higher amounts of transpiration through the plant and grass leaf stomata respectively. From the simulated result, the safe yield of the basin can be assumed to be 25 percent of the total estimated recharge which is $17.2 \mathrm{~mm} / \mathrm{year}$. 
Therefore, $17.2 \mathrm{~mm}$ of groundwater can be safely abstracted annually without adversely affecting the groundwater resource of the catchment (Fig 12). The distributed safe yield estimation taking $25 \%$ of the recharge estimated is shown on figure 12 .

\section{CONCLUSION}

The uneven distributions of the climatic parameters associated with variations of land-use/landcover, soil type, topography and slope are responsible for variations of the water balance element within the catchment.

The largest amount of evapotranspiration simulated for the catchment, relative to the groundwater recharge and the surface runoff, indicates that much effort is needed to change the environmental conditions of the catchment by applying some soil and water conservation practices.

By assuming $25 \%$ of the annual groundwater recharge can safely be abstracted, about $17.2 \mathrm{~mm}$ of the recharged water can be abstracted annually in a sustainable manner without having an adverse effect in the groundwater resource.

The result of WetSpass model can improve further if more seasonal groundwater depth data and new meteorological stations become available. Then, since the meteorological stations are located in the vicinity of Mekelle town with uneven distribution, additional meteorological station in the eastern part of the catchment around Araguren should be established.

\section{REFERENCES}

Alemaw, B.F \& Chaoka, T.R. 2003. A continental scale water balance model: a GIS approach for Southern Africa. Physics and Chemistry of the Earth, 28: 957-966.

Batelaan, O \& DeSmedt, F. 2001. WetSpass: a flexible, GIS based, distributed recharge methodology for regional groundwater modeling. Proceedings of a symposium held during the Sixth IAHS Scientific Assembly at Maastricht, The Netherlands, July 2001, IAHS Publication, 269:117p.

Batelaan, O \& DeSmedt, F. 2007. GIS based recharge estimation by coupling surface-subsurface water balance. Journal of hydrology, 337:337-355. 
Crosbie, R., Jolly, L., Leaney, F., Petheram, C\& Wohling, D. 2010. Review of Australian groundwater recharge studies CSIRO: water for a healthy country National Research Flagship, 81p.

Fetter, C. W. 2001. Applied hydrogeology. $4^{\text {rth }}$ Edition, Upper Saddle River, Prentice Hall.

Gebreryfael, H. 2008. Groundwater resource assessment through distributed steady-state flow modeling, Aynalem well field. Mekelle, Ethiopia. MSc Thesis, International Institute for Geo-Information Science and Earth observation enschede, The Netherlands (unpubl).

Girmay, K. 2011.Aquifer characterization and groundwater quality for irrigation in Illala catchment. MSc Thesis, Mekelle University, Ethiopia (unpubl).

Samuel, Y. 2003. Hydrogeology of Illala-Aynalem catchment with particular reference to the chemical variation and aquifer characterization. MSc thesis, Addis Ababa University, Ethiopia (unpubl).

Seleshi, Y. 2002. Estimation of reference evapotranspiration (ETO) for areas within adequate meteorological data in Ethiopia: Journal of engineers and architects, Addis Ababa, Ethiopia, 19:21-28.

Tesfamichael, G. 2009. Regional groundwater flow modeling of the Geba basin, Northern Ethiopia. PhD Thesis, Vrije Universiteit, Brussel (unpubl).

Tesfaye, C \& Gebrestadikan, E. 1978. Hydrogeological map of Mekelle: Ethiopian mapping agency.

Tesfaye, C \& Gebrestadikan, E. 1982. Hydrogeology of the Mekelle area (N D37-11). Ministry of mines and energy Ethiopian Institute of Geological Surveys.

Water Works Design and Supervision Enterprise (WWDSE), 2007. Evaluation of Aynalem well field and selection of additional prospective bore holes for Mekelle town water supply sources. Report, Vol. II, Addis Ababa, Ethiopia.

Yongxin, X \& Beekman, H. E. 2003. Groundwaters recharge estimation in Southern Africa. Paris: United Nations Educational Scientific and Cultural Organization

Zeru, G. 2008. Evaluation of groundwater potential using modeling (mudflow). MSc thesis, Mekelle University, Ethiopia (unpubl). 